\title{
COVID-19 AND STIGMATISATION OF HEALTHCARE PROVIDERS
}

\author{
Tahir Belice \\ Department of Internal Diseases ${ }^{I}$ \\ drtahirelf@hotmail.com \\ Dilan Çiftçi \\ Department of Hematology $y^{l}$ \\ dilanciftci96@gmail.com \\ Ismail Demir \\ Department of Internal Diseases ${ }^{1}$ \\ drismaildemir@hotmail.com \\ Arif Yüksel \\ Department of Internal Diseases ${ }^{1}$ \\ ayuksel68@gmail.com \\ ${ }^{1}$ University of Health Sciences \\ Izmir Bozyaka Training and Research Hospital \\ 59 Saim Çıkrıçı str., Izmir, Turkey, 35360
}

\begin{abstract}
The aim: this study presents a Coronavirus Stigma Scale for Healthcare Providers that indicates the social stigmatisation rate and severity toward healthcare providers to a certain extent. This paper aims at raising awareness on the stigmatisation of healthcare providers who sacrifice their own lives for patients diagnosed or are at risk of being infected with COVID-19.

Methods: the study uses a 12-item 5-point Likert-type Coronavirus Stigma Scale for Healthcare Providers, which was constructed based on the previously shortened and modified HIV Stigma Scale. The scale was distributed online to healthcare providers, and all the results obtained were then saved to an Excel file. Correlations were determined by using ANOVA and the independent $t$-test. Percentages, averages, figures and rates were calculated with SPSS.

Results: the population of the study comprised 136 participants in total; 40 male and 96 female. Reliability and validity studies were conducted using Cronbach's alpha and factor analysis. The stigmatisation rate toward healthcare providers was found to be significantly high, and the stigmatisation level was found to increase significantly with increasing age $(p<0.05)$.

Conclusions: the mistreatment of stigmatised healthcare providers during a pandemic where the need for them is elevated results in adverse outcomes; therefore, anti-stigma programmes need to be developed. It would be wise to find solutions such as acknowledging the stigma and introducing anti-stigma programmes.
\end{abstract}

Keywords: COVID-19, social stigma, health personnel, pandemics.

DOI: $10.21303 / 2504-5679.2020 .001447$

\section{Introduction}

Stigma leads to rejection of an individual or of a group by society and increases the level of social inequality, which might turn into discrimination of varied types and magnitudes causing serious social problems up to a level where personal resources are restricted [1].

The globally acknowledged notion of stigma and related pathologies, with their causes and outcomes set forth by numerous studies, are known to disrupt the obtaining of healthcare services, compliance to treatment and suppression of active participation in patient care and protection [1-3].

Throughout the course of time, the emergence of, particularly, disease stigma when patients are the most desperate and are in need of help have caused significant social and health problems. Characterisation of patients as 'corrupt, filthy or lazy' led to increased social violence. Thus, 
it became harder for these fragile and helpless people to receive treatment or support. Furthermore, they were even prevented from receiving treatment.

For instance, Irish immigrants were believed to be the root of epidemic diseases in $19^{\text {th }}$ century America, as they were perceived as being 'filthy, inconsiderate people that lacked hygiene' [4].

Similarly, as African-American people died of tuberculosis during the beginning of the $20^{\text {th }}$ century, white Americans were advised against living or working close to them instead of concentrating on providing diagnosis and treatment to these people [5].

Numerous examples of stigma can be found in literature, where the most common types can be listed as stigmas against obesity, mental illnesses, epilepsy, cancer, AIDS, leprosy, Ebola and so on. During the Ebola pandemic in West Africa, 11,000 people lost their lives while 17,000 people survived after they were infected, and the survivors continued their lives struggling with physical and mental health problems of different magnitudes $[6,7]$.

During the Ebola crises, social stigmatisation was unforgettably common; for instance, the case of an Ebola survivor who was not let into his own house and was rejected by his neighbours although his repeated test results returned negative after 3 weeks of isolation is hardly unique [8].

Significant disruptions are also observed in the case of obese patients receiving treatment or complying with their treatment due to the stigma toward the obese, as obesity has become a global pandemic of the new age. As an example of this fact, several studies demonstrated that obese patients were less often admitted to cancer screenings [9-11].

Hence, it was concluded that preventive medicinal measures could not fully be executed on obese patients.

Similarly, epileptic patients are subjected to various types of stigmatisation, particularly in regards to admittance into certain fields of business (prohibition of heavy machinery use), being considered an outcast or an individual to be scared of in school life or an individual with handicaps whose thoughts and actions shall constantly be intervened by their family (either in a conscious or an unconscious manner) $[12,13]$.

Furthermore, the number of people diagnosed with HIV increased as a result of improved healthcare systems and gained access to anti-retroviral treatments; and as such, visits paid by these individuals to health institutions for growing incidences of non-contagious diseases such as diabetes mellitus, depression and cancer also increased in frequency $[14,15]$. Nevertheless, stigma and discrimination toward individuals with HIV results in them receiving either poor or delayed service from healthcare institutions [16]. A case study from India demonstrated that only $39.2 \%$ of the dentists were willing to treat patients who had HIV [17].

This study was conducted with the understanding that the increased prevalence of social stigma experienced by healthcare providers during a pandemic calls for the creation of a stigma scale exclusively for healthcare providers, and that the stigma levels of healthcare providers shall thus be measured.

The aim of the research is to show the level of the stigmatization of healthcare workers during the pandemic.

\section{Method}

A 12-item 5-point Likert-type Coronavirus Stigma Scale for Healthcare Providers was constructed based on the shortened HIV Stigma Scale, the validity and reliability of which had been proven (Table 1) [18].

The 5-point Likert-type scale was used for the study from 01.04.2020 to 30.04.2020. An online link for the survey comprising questions related to age and gender of the participants and the 12-item scale was created and sent to healthcare providers through social media platforms and WhatsApp application. Intergroup correlations were determined using the ANOVA and independent t-tests.

The relevant percentages, rates, figures, validity and reliability tests were calculated on the SPSS software, and the obtained data were then recorded. 
Table 1

Items of Scale both in Turkish and English

\section{Sağlık Çalışanları Coronavirus Stigma Ölçeği İfadeleri}

\section{Healthcare Workers Coronavirus Stigma Scale Items}

1-Görüştüğüm insanlar sağlıkçı olduğumu öğrenince benden uzaklaştılar.

People I care about stopped calling after learning I am a healthcare worker

2-Arkadaşlarıma Covid-19 tanısı alan hastalarım olduğunu söylediğim için onları kaybettim.

I have lost friends by telling them I have patients diagnosed with COVID-19

3-Covid-19 hastalarının olduğu bir hastanede çalıştı̆̆ımı öğrenince bazı arkadaşlarım bana dokunmaktan kaçındı.

Some people avoid touching me once they know I work in a hospital

4-Covid-19 hastalarım olduğunu gizlemeye çalıştım.

I work hard to keep my touch in with COVID-19 patients a secret

5-Birinin Covid-19 hastalığım olabileceğini düşünmesi risklidir.

Telling someone I may have COVID-19 is risky

6-Birine Covid-19 hastaları ile çalışıp çalışmadığımı söylemeye çok dikkat ederim.

I am very careful who I tell that I work at around the patients diagnosed with COVID-19

7-Bir çok insan Covid-19 tanısı almış kişilerin pis ve kirli olduğuna inanıyor.

Most people believe a person who has COVID-19 is dirty

8-Covid-19 tanısı almış hastalar toplumdan dişlanıyor.

People with COVID-19 are treated like outcasts

9-Birçok insan Covid-19 hastaları ile çalışanlardan uzak durmaya çalışıyor.

Most people are uncomfortable around healthcare workers who work for patients with COVID-19

10-Bende Covid-19 hastalık riskinin olması kendimi suçlı hissetmeme neden oluyor.

I feel guilty because I have a risk of being COVID-19

11-İnsanların Covid-19 hastalarına olan davranış ve tutumları kendimi daha da kötü hissetmeme neden olmaktadır.

People's attitudes about COVID-19 make me feel worse about myself

12-Sürekli Covid-19 hastalığına yakalanma riskimin olması diğer insanlar kadar iyi olmadığımı hissetmeme neden olmaktadır.

I feel I'm not as good a person as others because I have a risk of being COVID-19

\section{Results}

A total of 136 individuals (40 male and 96 female) participated in the study. The maximum total score for the scale was 60, and through the adaptation of the HIV Stigma Scale, the individuals scoring above 25 were termed to be stigma-negative. Consequently, 28 of the participants (20.6\%) were observed to have no stigma whereas the remaining 108 participants $(79.4 \%)$ were found to have stigma levels at the pathological margin. The average total scale score for males was found to be $32.6 \pm 10.9$, whereas the average total score for females was $35.8 \pm 9.5$. The validity and reliability tests were found to be affirmative. Reliability was tested with Cronbach's alpha and found at a level of 0.85 , where all of the items had a value exceeding 0.7. The Kaiser-Meyer-Olkin test result was 0.847 , and the Barlett test result was found to be significant. Three components were identified as a result of the factor analysis. The $1^{\text {st }}, 2^{\text {nd }}$ and $3^{\text {rd }}$ items were grouped into the $2^{\text {nd }}$ component (personalised stigma); $4^{\text {th }}, 5^{\text {th }}$ and $6^{\text {th }}$ items were grouped into the $3^{\text {rd }}$ component (disclosure concerns); and the remaining items were grouped into the $1^{\text {st }}$ component (concerns about public attitudes and negative self-image). No significant difference was found between the total scale scores of male and female participants $(p>0.05)$. The average age of the participants was found to be $31.23 \pm 8.764$. The total scale score was observed to decrease with increasing age and this decrease was found to be statistically significant $(p<0.05)$.

\section{Discussion}

The etymological roots of the word stigma suggest that the word is historically inherited from the Ancient Greek language, and it was used as a reference to mark slaves, criminals and excommunicates with tattoos or brands [19]. In the course of time, the notion was used to serve similar purposes in different cultures and fields [20]. Sociologist Erving Goffman suggested the existence of a pattern between stigma and ethnicity or race, physical defects and individual personality disorders (such as addictions or mental illnesses) [3]. Moreover, Scambler and Hopkins 
divided stigma into two types; namely, enacted stigma and felt stigma [12]. Stigma in itself was later investigated by numerous scientists under eight distinct groups (public stigma, label stigma, self-stigma, structural stigma, courtesy stigma, stigma power, automatic stigma and double or multiple stigmas) [21]. Currently, it is believed that stigma and related health problems have increased even more and reached critical levels due to social media tools and their usage [22]. Indeed, observations revealed that it was not only healthcare providers that faced social stigma but various mental and physical diseases or social status/statuses were also being stigmatised. Consequently, these psychopathological attitudes and behaviour models became subjects of different fields, and adding the complexity of such cases to this fact, it became challenging to find viable solutions to the problem [23].

Earlier studies were conducted on common social stigmatisation and its potential health effects during the Ebola epidemic and on the obesity pandemic. Recently, in our workplaces or on social media, we witnessed that healthcare providers were being stigmatised and mistreated because of the COVID-19 pandemic. We, therefore, acted fast to create a scale with the aim of determining the levels of stigma experienced by healthcare providers, which would, in turn, determine the severity of the situation. Stigma levels were found to be high in the online study conducted with the participation of the healthcare providers working at central Izmir hospitals. Therefore, we believe that this result can act as a warning sign for us to promptly plan and execute anti-stigma measures. It is not acceptable for the devotedly working healthcare providers, who put their own lives at risk to save the lives of others during the novel Coronavirus pandemic, to be mistreated through social stigmatisation and to live their lives in a demoralised state [24]. Hence, social awareness on the subject matter should be raised, while the prevalence and severity of stigmatisation should be minimised through relevant and effective measures.

Study limitations. The present study has various limitations. First, we did not acquire information on the prevalence of mental illnesses such as anxiety or depression. Second, the type and intensity of cultural and regional background in which the participants engaged were not determined.

Prospects for further research. Not only healthcare providers but also the survivors of COVID-19 should be taken into account regarding stigmatization in further studies, so anti-stigma programs need to be in action. Further research would refer to this study to compare other groups of populations for a new synthesis, which could give an idea to find possible practical solutions for stigmatization.

\section{Conclusions}

The present study indicates the high level of stigmatization of healthcare workers during pandemic. In these challenging times of the novel Coronavirus pandemic, where we need healthcare providers the most, it is of utmost importance to implement awareness practices by foreseeing the adverse outcomes of the tendencies toward stigmatisation and to minimise the levels of stigmatisation by using institutional and social media tools for this purpose.

\section{Conflict of interests}

The authors declare that they have no conflicts of interest.

\section{References}

[1] Link, B., Hatzenbuehler, M. L. (2016). Stigma as an Unrecognized Determinant of Population Health: Research and Policy Implications. Journal of Health Politics, Policy and Law, 41 (4), 653-673. doi: http://doi.org/10.1215/03616878-3620869

[2] Mahajan, A. P., Sayles, J. N., Patel, V. A., Remien, R. H., Sawires, S. R., Ortiz, D. J. et. al. (2008). Stigma in the HIV/AIDS epidemic: a review of the literature and recommendations for the way forward. AIDS, 22 (2), 57-65. doi: http://doi.org/10.1097/ 01.aids.0000327438.13291.62

[3] Goffman, E. (1963). Stigma: notes on the management of spoiled identity. New York: Simon \& Schuster Inc., 147.

[4] Kraut, A. M. (1994). Silent travelers: germs, genes, and the «immigrant menace.» Baltimore: Johns Hopkins University Press, 384.

[5] Pomeranz, J. L. (2008). A Historical Analysis of Public Health, the Law, and Stigmatized Social Groups: The Need for Both Obesity and Weight Bias Legislation. Obesity, 16 (S2), S93-S103. doi: http://doi.org/10.1038/oby.2008.452 
[6] Ebola situation report (2015). World Health Organization. Available at: http://apps.who.int/ebola/current-situation/ebolasituation-report-15-april-2015

[7] Vetter, P., Kaiser, L., Schibler, M., Ciglenecki, I., Bausch, D. G. (2016). Sequelae of Ebola virus disease: the emergency within the emergency. The Lancet Infectious Diseases, 16 (6), e82-e91. doi: http://doi.org/10.1016/s1473-3099(16)00077-3

[8] Dearden, L. (2015). Ebola survivor beat disease only to be left by husband and ostracised because of stigma. Independent. Available at: http://www.independent.co.uk/news/world/africa/ebola-survivor-beat-disease-only-to-be-left-by-husband-andostracised-because-of-stigma-10029606.html

[9] Ferrante, J. M., Ohman-Strickland, P., Hudson, S. V., Hahn, K. A., Scott, J. G., Crabtree, B. F. (2006). Colorectal cancer screening among obese versus non-obese patients in primary care practices. Cancer Detection and Prevention, 30 (5), $459-465$. doi: http://doi.org/10.1016/j.cdp.2006.09.003

[10] Mitchell, R. S., Padwal, R. S., Chuck, A. W., Klarenbach, S. W. (2008). Cancer Screening Among the Overweight and Obese in Canada. American Journal of Preventive Medicine, 35 (2), 127-132. doi: http://doi.org/10.1016/j.amepre.2008.03.031

[11] Wee, C. C., McCarthy, E. P., Davis, R. B., Phillips, R. S. (2000). Screening for Cervical and Breast Cancer: Is Obesity an Unrecognized Barrier to Preventive Care? Annals of Internal Medicine, 132 (9), 697-704. doi: http://doi.org/10.7326/ 0003-4819-132-9-200005020-00003

[12] Scambler, G., Hopkins, A. (1986). Being epileptic: coming to terms with stigma. Sociology of Health and Illness, 8 (1), $26-43$. doi: http://doi.org/10.1111/1467-9566.ep11346455

[13] Schneider, J. W., Conrad, P. (1980). In the Closet with Illness: Epilepsy, Stigma Potential and Information Control. Social Problems, 28 (1), 32-44. doi: http://doi.org/10.2307/800379

[14] Hirschhorn, L. R., Kaaya, S. F., Garrity, P. S., Chopyak, E., Fawzi, M. C. S. (2012). Cancer and the «other» noncommunicable chronic diseases in older people living with HIV/AIDS in resource-limited settings. AIDS, 26, S65-S75. doi: http://doi.org/ 10.1097/qad.0b013e328355ab72

[15] Chibanda, D., Benjamin, L., Weiss, H. A., Abas, M. (2014). Mental, Neurological, and Substance Use Disorders in People Living With HIV/AIDS in Low- and Middle-Income Countries. JAIDS Journal of Acquired Immune Deficiency Syndromes, 67, S54-S67. doi: http://doi.org/10.1097/qai.0000000000000258

[16] Nyblade, L., Stangl, A., Weiss, E., Ashburn, K. (2009). Combating HIV stigma in health care settings: what works? Journal of the International AIDS Society, 12 (1), 15. doi: http://doi.org/10.1186/1758-2652-12-15

[17] Agarwal, J., Agarwal, R. S., Shrivastava, A., Shrivastava, S. (2015) Analysis of Information, Impact and Control of HIV amongst Dental Professionals of Central India. Journal of clinical and diagnostic research, 9 (7), ZC80. doi: http://doi.org/ $10.7860 /$ jcdr/2015/14300.6236

[18] Reinius, M., Wettergren, L., Wiklander, M., Svedhem, V., Ekström, A. M., Eriksson, L. E. (2017). Development of a 12-item short version of the HIV stigma scale. Health and Quality of Life Outcomes, 15 (1). doi: http://doi.org/10.1186/s12955-017-0691-z

[19] Tzouvara, V., Papadopoulos, C. (2014). Public stigma towards mental illness in the Greek culture. Journal of Psychiatric and Mental Health Nursing, 21 (10), 931-938. doi: http://doi.org/10.1111/jpm.12146

[20] Markowitz, F. E., Engelman, D. J. (2016). The «Own» and the «Wise»: Does Stigma Status Buffer or Exacerbate Social Rejection of College Students with a Mental Illness? Deviant Behavior, 38 (7), 744-755. doi: http://doi.org/10.1080/01639625.2016.1197673

[21] Sheehan, L., Nieweglowski, K., Corrigan, P. W. (2016). Structures and Types of Stigma. The Stigma of Mental Illness End of the Story? Springer, 43-66. doi: http://doi.org/10.1007/978-3-319-27839-1_3

[22] Betton, V., Borschmann, R., Docherty, M., Coleman, S., Brown, M., Henderson, C. (2015). The role of social media in reducing stigma and discrimination. British Journal of Psychiatry, 206 (6), 443-444. doi: http://doi.org/10.1192/bjp.bp.114.152835

[23] Saillard, E. (2009) Psychiatrist views on stigmatization toward people with mental illness and recommendations. Türk Psikiyatr Derg, 21 (1), 14-24.

[24] Kamışl1, S., Dil, S., Daştan, L., Eni, N. (2016). Feeling of liberty and internalized stigma: comparison of inpatient and outpatient cases receiving psychiatric treatment. Turkish Journal of Psychiatry, 27 (4), 251-256. doi: http://doi.org/10.5080/u14927 